\title{
KREATIVITAS BERFIKIR, TEKNIK PENULISAN DAN PENGUASAAN METODOLOGI PENELITIAN: Analisis Terhadap Kualitas Skripsi Mahasiswa STAIN Jurai Siwo Metro
}

\author{
Kuryani \\ Institut Agama Islam Negeri (IAIN) Metro \\ Jl. Ki Hajar Dewantara, 15 A Iring Mulyo Metro Timur, Metro, Lampung 34111 \\ Email:kuryaniutih@yahoo.co.id
}

\begin{tabular}{|l|l|l|}
\hline Diterima: 10 Maret 2017 & Revisi:20 April 2017 & Disetujui: 5 Mei 2017 \\
\hline
\end{tabular}

\begin{abstract}
Undergraduate Thesis (Skripsi) is one of the scientific writing that should be written by the students before finishing their study at a university. It is also called scientific wrtting because it shoul be written logically, systematically and originally. For good scientific writing, the students need to the thinking creativity, writing technique, and research methodology mastery.The aim of this research is know the quality of undergraduate thesis written by the students of State Islamic College (STAIN) Jurai Siwo Metro in the period of 2010-2015. This research had been conducted in STAIN Jurai Siwo Metro Library by observing and anlysing the tudents' undergraduate thesis that written in those periods. Based on the finding of research can be identified that the quality of students undergraduate thesis still in low level. The low quality of students' undergraduate thesis caused by 69,60\% of students had lack of thinking creativity, $64,61 \%$ of students could not write perfectly in writing technique, and $64,57 \%$ of students didn't master the research methodology. This low quality was not only made by the students. But also there were many factors that can influence the case. The lecuters and the sponsors were also had strategis role in their writing. But more over the students should be studying hard to be able and master thinking creavity, writing technique dan research methodology.
\end{abstract}

Keywords: Undergraduated Thesis, Thinking Creativity, Writing Technique, Research Methodology Mastery 


\begin{abstract}
Abstrak
Skripsi merupakan salah satu tulisan ilmiah yang harus ditulis oleh para siswa sebelum menyelesaikan studinya di universitas. Hal ini juga disebut wrtting ilmiah karena harus ditulis secara logis, sistematis dan awalnya. Untuk penulisan ilmiah yang baik, para siswa perlu adanya kreativitas berfikir, teknik penulisan, dan penguasaan metodologi penelitian. Tujuan dari penelitian ini adalah mengetahui kualitas tesis sarjana yang ditulis oleh mahasiswa Fakultas Ekonomi Negeri Islam (STAIN) Jurai Siwo Metro pada periode tersebut. Dari 2010-2015. Penelitian ini telah dilakukan di Perpustakaan STAIN Jurai Siwo Metro dengan mengamati dan menganalisa tesis sarjana yang ditulis pada periode tersebut. Berdasarkan temuan penelitian dapat diketahui bahwa kualitas tesis sarjana mahasiswa masih rendah. Rendahnya kualitas tesis sarjana siswa yang disebabkan oleh 69,60\% siswa memiliki kreativitas berfikir kurang, 64,61\% siswa tidak dapat menulis dengan sempurna dalam teknik penulisan, dan $64,57 \%$ siswa tidak menguasai metodologi penelitian. Kualitas rendah ini tidak hanya dibuat oleh para siswa. Tapi ada juga banyak faktor yang bisa mempengaruhi kasus tersebut. Pelaku dan sponsor juga memiliki peran strategis dalam tulisan mereka. Tetapi lebih pada siswa harus belajar keras untuk bisa dan menguasai ingatan, teknik penulisan dan metodologi penelitian.
\end{abstract}

Kata kunci : Tesis Terahir, Kreativitas Berpikir, Teknik Menulis, Metodologi Penelitian Penguasaan

\title{
A. Pendahuluan
}

Perguruan Tinggi merupakan salah satu lembaga yang memiliki tugas utama menyelenggarakan pendidikan dan pengajaran, melaksanakan penelitian dan melakukan pengabdian pada masyarakat. Sebagai lembaga pendidikan tinggi, perguruan tinggi memiliki tanggung jawab untuk menyiapkan genarasi muda yang berkualitas, memiliki integritas, kerativitas, dan moralitas yang tinggi sebagai generasi penerus bangsa. Oleh karena itu, perguruan tinggi memiliki peran strategis dalam mencerdaskan kehidupan berbangsa dan bernegara. 
Sekolah Tinggi Agama Islam Negeri (STAIN) Jurai Siwo Metro merupakan salah satu perguruan tinggi di Kota Metro yang menyelenggarakan pendidikan program Diploma 3 (D3), sarjana (S1), dan pascasarjana (S2). STAIN Jurai Siwo Metro memiliki misi: Menjadi Perguruan Tinggi Agama Islam yang Inovatif dalam sinergi socio-ecotechno-preneurship berlandaskan nilai-nilai keislaman dan keindonesiaan. Saat ini, STAIN Jurai Siwo Metro memiliki 6.079 mahasiswa yang terdistribusi dalam 2 program studi pascasarjana (S2), proram 11 sarjana (S1), dan 1 program studi Diploma 3 (D3). Bagi mahasiswa program sarjana (S1) berkewajiban untuk menulis skripsi sebagai karya tulis ilmiah sekaligus sebagai tugas akhir dalam menyelesaikan pendidikannya.

Sebagai karya tulis ilmiah, skripsi harus ditulis dan disusun berdasarkan kaidah-kaidah ilmiah dan berpedoman pada buku pedoman penulisan karya ilmiah yang telah ditetapakan oleh STAIN Jurai Siwo Metro. Selain itu, dalam teknis penulisannya setiap mahasiswa dibimbing dan diarahkan oleh dua orang dosen pembimbing skripsi. Namun demikian, secara keseluruhan isi dan materi penulisan sepenuhnya adalah merupakan tanggung jawab mahasiswa. Sebuah skripsi ditulis dan disusun berdasarkan hasil penelitian yang dilakukan oleh mahasiswa, baik studi lapangan, kepustakaan atau laboratorium. Sehingga diharapkan bahwa skripsi mahasiswa adalah benar-benar berdasarkan hasil kajian secara ilmiah. Di STAIN Jurai Siwo Metro, skripsi ditulis dalam 3 bahasa, yaitu: 1). berbahasa Arab, bagi mahasiswa program studi Pendidikan Bahasa Arab, 2) berbahasa Inggris, bagi mahasiswa program studi Tadris Bahasa Inggris, dan 3) berbahasa Indonesia, bagi mahasiswa selain kedua program studi tersebut.

Sebelum sampai pada tahapan penulisan skripsi, selama proses perkuliahan, mahasiswa telah dibelakali dengan beberapa mata kuliah yang berkaitan dengan penulisan skripsi. Mata kuliah tersebut antara lain : Bahasa Indonesia, bahasa Inggris, bahasa Arab, metodologi penelitian, ilmu statistic dan karya tulis ilmiah. Keseluruhan mata kuliah tersebut diharapkan

\footnotetext{
2015

1 Data Subbag Akademik, Kemahasiswaan dan Alumni STAIN Jurai Siwo Metro, Tahun 
akan dapat membantu dan mempermudah mahasiswa dalam penulisan dan penyusunan skripsi. Selanjutnya, pada tahapan teknik penulisan, mahasiswa juga telah dibekali dengan buku pedoman dan dibimbing oleh 2 orang dosen pembimbing skripsi. Dengan demikian, skrispi yang ditulis oleh mahasiswa diharapkan dapat menjadi sebuah karya tulis yang memenuhi kaidahkaidah ilmiah, yang ditulis secara sistematis, logis dan ilmiah. Namun pada kenyataannya, sampai dengan saat ini sejumlah skripsi yang ditulis oleh mahasiswa STAIN Jurai Siwo Metro dapat dikatakan belum memiliki kualitas yang baik.

Untuk menghasilakn sebuah karya tulis ilmiah, selain dibekali dengan berbagai disiplin keilmuan, mahasiswa juga dituntut untuk memiliki kreativitas berfikir menguasai teknik penulisan, dan pemahaman metode penelitian. Oleh karena itu, tulisan ini akan membahas Kreativitsa berfikir, teknik penulisan dan penguasaan metodologi penelitian: analisis terhadap Kualitas Skripsi Mahasiswa STAIN Jurai Siwo Metro.

\section{B. Kualitas Skripsi Mahasiswa STAIN Metro}

\section{Skripsi dan Pengertiannya}

Skripsi merupakan karya tulis ilmiah yang ditulis oleh mahasiswa sebagai tugas akhir dalam rangka menyelesaikan studinya pada program sarjana (S1). Dalam penulisan skripsi mahasiswa dibimbing oleh dosen pembimbing skripsi dengan mengacu kepada buku panduan penulisan karya ilmiah yang telah ditetapkan oleh masing-masing perguruan tinggi. Dengan demikian, menulis skripsi adalah merupakan kewajiban bagi mahasiswa yang menempuh studi program sarjana (S1). Melalui pembimbingan oleh dosen pembimbing dalam penulisan skripsi, diharapkan skripsi yang ditulis mahasiswa dapat memenuhi standar penulisan karya tulis ilmiah yang berkualitas baik.

Pengertian skripsi menurut Machdar Helmi; Skripsi merupakan karya tulis ilmiah berdasarkan hasil penelitian lapangan dan atau studi 
kepustakaan yang disusun mahasiswa sesuai dengan bidangstudinya sebagai tugas akhir dalam studi formalnya di Perguruan Tinggi. Skripsi dalam dunia pendidikan berarti suatu hasil penyusunan tulisan ilmiah yang telah dibuktikan kebenarannya berdasarkan data-data yang telahdikumpulkan dan tentunya data yang dikumpulkan diolah untuk kemudian menjadi data yang valid sebagai bahan acuan buat membuktikan kebenaran suatu tulisan tersebut. ${ }^{2}$

Sementara itu menurut Rahyono FX, skripsi adalah laporan tertulis hasil penelitian yang dilakukan oleh mahasiswa dengan bimbingan Dosen Pembimbing Skripsi untuk dipertahankan di hadapan Penguji Skripsi sebagai syarat untuk memperoleh derajat Sarjana. Skripsi merupakan karya tulis ilmiah berdasarkan hasil penelitian yang dilakukan oleh seorang mahasiswa sebagai tugas akhir untuk memperoleh gelar sarjana. ${ }^{3}$

Sedangkan Munslich Mansur mendefiniskan skripsi adalah istilah yang digunakan di Indonesia untuk mengilustrasikan suatu karya tulis ilmiah berupa paparan tulisan hasil penelitian sarjana S1 yang membahas suatu permasalahan/fenomena dalam bidang ilmu tertentu dengan menggunakan kaidah-kaidah yang berlaku. Skripsi merupakan karya tulis ilmiah berdasarkan hasil penelitian lapangan dan atau studi kepustakaan yang disusun mahasiswa sesuai dengan bidang studinya sebagai tugas akhir dalam studi formalnya di Perguruan Tinggi. Skripsi adalah karya ilmiah yang ditulis mahasiswa program S-1 yang membahas topik atau bidang tertentu berdasarkan hasil kajian pustaka yang diteliti oleh para ahli, hasil penelitian lapangan atau hasil pengembangan atau eksperimen. ${ }^{4}$

Mencermati ketiga pengertian skripsi di atas, dapat dipahami bahwa skripsi adalah suatu karya tulis ilmiah yang disusun oleh mahasiswa berdasarkan hasil penelitian yang dilakukan oleh mahasiswa sesuai dengan bidang studi atau disiplin keilmuannya. Penelitian mahasiswa dapat

2 https://machdarhelmi.wordpress.com.

3 https://v17a3.wordpress.com

4 https://machdarhelmi.wordpress.com. 
dilakukan di lapangan, perpustakaan atau penelitian pengembangan / eksperimen. Skripsi ditulis oleh mahasiswa program sarjana (S1) sebagai salah satu syarat untuk memperoleh gelar sajana berdasarkan kosentrasi dan bidang keilmuannya.

Penulisan skripsi bagi mahasiswa memiliki maksud, makna dan tujuan tertentu. Penulisan skripsi dilaksanakan dengan tujuan agar:

a) Mahasiswa mampu menyusun dan menulis suatu karya ilmiah, sesuai dengan bidang ilmu yang ditempuh.

b) Mahasiswa mampu melakukan penelitian mulai dari merumuskan masalah, mengumpulkan data, mengolah data, menganalisis data, dan menarik suatu kesimpulan.

c) Membantu mahasiswa menyampaikan, menggunakan, mengaplikasi-kan ilmu dan pengetahuan yang diperoleh menjadi suatu sistem yang terpadu untuk pengembangan ilmu. ${ }^{5}$

Seyognya skripsi yang ditulis mahasiswa harus berkualitas baik, karya sendiri (original) bukan hasil plagirisme, ilmiah dan dapat dipertanggung jawabkan di depan sidang pengujian skripsi. Untuk menghasilkan skripsi yang memiliki kualifikasi tersebut, dibutuhkan kreativitas berfikir mahasiswa, pemahaman teknik penulisan dan penguasaan metodologi penelitian. Ketiga hal ini merupakan fokus penelitian yang akan dibahas dalam tulisan ini.

\section{Rancangbangun dan Kreativitas Berfikir Mahasiswa}

Rogers dalam Utami Munandar, mengemukakan kreativitas merupakan kecenderungan untuk mengaktualisasi diri, mewujudkan potensi, dorongan untuk berkembang dan menjadi matang, kecenderungan untuk mengekspresikan dan mengaktifkan semua kemampuan organisme. ${ }^{6}$

\footnotetext{
5 http://iesp.feb.unpad.ac.id

6 Utami Munandar, Pengembangan Kreativitas Anak Berbakat, (Jakarta: Renika Cipta, 2009), h. 18
} 
Definisi lain menurut Moreno dalam Yatim Riyanto, kreativitas merupakan sesuatu yang baru bagi diri sendiri dan tidak harus merupakan sesuatu yang baru bagi oranglain atau dunia pada umumnya, misalnya seorang siswa menciptakan untuk dirinya sendiri suatu hubungan baru dengan siswa/orang lain. ${ }^{7}$

Munandar mengatakan ciri-ciri kemampuan kreativitas yang berhubungan dengan kognisi dapat dilihat dari keterampilan berfikir lancar, keterampilan berfikir luwes, keterampilan berfikir orisinil, dan keterampilan menilai. Keterampilan berfikir lancar memiliki ciri-ciri: (1) mencetuskan banyak gagasan dalam menyelesaikan masalah; (2) memberikan banyak cara atau saran untuk melakukan berbagai hal; (3) bekerja lebih cepat dan melakukan lebih banyak daripada yang lain. Kemampuan berfikir luwes mempunyai ciri-ciri: (1) menghasilkan gagasan penyelesaian masalah atau jawaban suatu pertanyaan yang bervariasi; (2) dapat melihat suatu masalah dari sudut pandang yang berbeda-beda; (3) menyajikan suatu konsep dengan cara yang berbeda. ${ }^{8}$

Berdasarkan pendapat para ahli di atas, maka kreativitas dapat dirumuskan sebagai suatu proses aktivitas kognitif seseorang untuk melahirkan sesuatu yang baru, baik berupa karya baru maupun karya kombinasi yang semuanya itu relatif berbeda dengan apa yang ada sebelumnya.

Menurut Utami Munandar, kreativitas adalah kemampuan seseorang untuk mengekspresikan ide-ide baru yang ada dalam dirinya sendiri. Adapun ciri-ciri dari kreativitas adalah:

(a) Rasa ingin tahu yang luas dan mendalam

(b) Sering mengajukan pertanyaan yang baik

(c) Memberikan banyak gagasan atau usul terhadap suatu masalah

7 Yatim Riyanto, Paradigma Baru Pembelajaran sebagai Referensi bagi Pendidik dalam Implementasi Pembelajaran yang Efektif dan Berkualitas, (Jakarta: Kencana, 2014), h. 233

8 Utami Munandar, Pengembangan Kreativitas Anak Berbakat..., h. 14 
(d) Bebas dalam menyatakan pendapat

(e) Mempunyai rasa keindahan yang dalam

(f) Menonjol dalam salah satu bidang seni

(g) Mampu melihat suatu masalah dari berbagai segi/sudut pandang

(h) Mempunyai rasa humor yang luas

(i) Mempunyai daya imajinasi

(j) Orisinal dalam ungkapan gagasan dan dalam pemecahan masalah. ${ }^{9}$

Kemampuan berfikir orisinil mempunyai ciri-ciri: (1) memberikan gagasan yang baru dalam menyelesaikan masalah; (2) membuat kombinasikombinasi yang tidak lazim dari bagian-bagian atau unsur-unsur. Kemampuan keterampilan memperinci (mengelaborasi) mempunyai ciri-ciri: (1) mengembangkan atau memperkaya gagasan orang lain; (2) menambah atau memperinci suatu gagasan sehingga meningkatkan kualitas gagasan tersebut. Sedangkan kemampuan keterampilan mengevaluasi mempunyai ciri-ciri: (1) dapat menentukan kebenaran suatu kebenaran pertanyaan atau kebenaran suatu rencana penyelesaian masalah; (2) dapat mencetuskan gagasan-gagasan penyelesaian suatu masalah dan dapat melaksanakannya dengan benar; dan (3) mempunyai alasan yang dapat dipertanggungjawabkan untuk mencapai suatu keputusan. ${ }^{10}$

Menurut Rothenberg dan Hausmen bahwa beberapa ahli mempunyai perbedaan pendapat mengenai kreativitas, namun terdapat persamaan diantaranya: (1) kreativitas berhubungan dengan sesuatu yang baru dan bernilai; (2) kreativitas meliputi seluruh aspek kehidupan termasuk dalam keilmuan matematik; (3) kemampuan kretivitas berbeda dengan kemampuan intelegensi, artinya walaupun intelegensinya tinggi belum tentu kreatif begitu pun sebaliknya; (4) setiap orang mempunyai potensi untuk kreatif jika memiliki sifat spontan dan terbuka. ${ }^{11}$

9 Ibid, h. 71

${ }^{10}$ Herdian: https://herdy07.wordpress.com posted 27 Mei 2010

${ }^{11}$ Ibid 
Menurut Stenberg dan Lubart berdasarkan investment theory of creativity yang mereka kembangkan bahwa terdapat enam atribut dari kreativitas yaitu kecerdasan (intelligence), pengetahuan (knowledge), motivasi (motivation), dukungan lingkungan (an encouragement environment), ketepatan cara atau gaya berfikir (appropriate thinking style), dan ketepatan person (an appropriate personality). ${ }^{12}$

Menurut Fisher, kreativitas adalah kemampuan dan sikap seseorang untuk membuat produk yang baru. Sedangkan menurut Evan dalam Fisher, kreativitas adalah kemampuan untuk menemukan kaitan-kaitan yang baru, lemampuan melihat sesuatu dari sudut pandang yang baru, dan kemampuan untuk membentuk kombinasi-kombinasi dari banyak konsep yang ada pada fikiran. ${ }^{13}$ Kreativitas menurut Haris, bukanlah mengadakan sesuatu yang tidak ada menjadi ada, akan tetapi kretivitas adalah kemampuan untuk menghasilkan ide-ide baru dengan cara membuat kombinasi, membuat perubahan, atau mengaplikasikan ide-ide yang ada pada wilayah yang berbeda. ${ }^{14}$

LTSIN (2001) secara khusus mendefinisikan berfikir kreatif adalah "creative thinking is the process which we use when we come up with a new idea.It is the merging of ideas which have not been merged before". LTSIN menyatakan bahwa berfikir kreatif adalah proses (bukan hasil) untuk menghasilkan ide baru dan ide itu merupakan gabungan dari ide-ide yang sebelumnya belum disatukan. ${ }^{15}$

Lebih detail lagi LTSIN (2001) menyatakan bahwa ide seseorang berfikir kreatif minimal mempunyai salah satu karakteristik dari: (a) ide itu belum ada sebelumnya; (b) sudah ada di tempat lain hanya saja ia tidak tahu; (c) ia menemukan proses baru untuk melakukan sesuatu; (d) ia menerapkan proses yang sudah ada pada area yang berbeda; (e) ia

\footnotetext{
${ }^{12}$ Ibid

${ }^{13}$ Fisher, R.Teaching Children to Think, (London: Stanley Thornes Ltd, 1995), h 11

${ }^{14}$ Fisher, Haris, R. Introduction to Creative Thinking. http://www.virtualsalt. com/itdt.htm

${ }^{15}$ LTSIN, Learning teaching, (Scotland: Learning and Teaching Scotland, 2004), h. 201
} 
mengembangkan sebuah cara untuk melihat sesuatu pada perspektif yang berbeda. Dari lima karakteristik diatas, kita dapat menyimpulkan bahwa berfikir kreatif dapat berupa ide baru yang belum ada sebelumnya dan dapat berupa ide baru sebagai penyempurnaan dari yang sudah ada sebelumnya. ${ }^{16}$

Kepekaan berfikir kreatif dapat diukur dengan indikator-indikator yang telah ditentukan para ahli, salah satunya menurut Torrance. Menurut Torrance kemampuan berfikir kreatif terbagi menjadi tiga hal, yaitu:

(a) Fluency (kelamcaran), yaitu menghasilkan banyak ide dalam berbagai kategori/bidang.

(b) Originality (Keaslian), yaitu memiliki ide-ide baru untuk memecahkan persoalan.

(c) Elaboration (Penguraian), yaitu kemampuan memecahkan masalah secara detail.

Sedangkan Guilford menyebutkan lima indikator berfikir kreatif, yaitu:

(1) Kepekaan (problem sensitivity), adalah kemampuan mendeteksi, mengenali, dan memahami serta menanggapi suatu pernyataan, situasi, atau masalah;

(2) Kelancaran (fluency), adalah kemampuan untuk menghasilkan banyak gagasan;

(3) Keluwesan (flexibility), adalah kemampuan untuk mengemukakan bermacam-macam pemecahan atau pendekatan terhadap masalah;

(4) keaslian (originality), adalah kemampuan untuk mencetuskan gagasan dengan cara-cara yang asli, tidak klise, dan jarang diberikan kebanyakan orang.

(5) Elaborasi (elaboration), adalah kemampuan menambah suatu situasi atau masalah sehingga menjadi lengkap, dan merincinya 
secara detail, yang didalamnya terdapat berupa tabel, grafik, gambar, model dan kata-kata. ${ }^{17}$

Kemampuan mengelaborasi menurut Munandar mempunyai ciri-ciri: 1) mengembangkan atau memperkaya gagasa orang lain, 2) menambah atau meperinci suatu gagasan sehingga meningkatkan kualitas gagasan tersebut. Sedangkan kemampuan mengaevaluasi mempunyai ciri-ciri: 1) dapat menentukan kebenaran suatu pertanyaan atau kenemaran suatu rencana penyelesaian masalah,2) dapat menceuskan gagasan penyelesaian suatu masalah dan dapat melaksanakannya dengan benar, dan 3) mempunyai alasan yang dapat dipertanggungjawabkan untuk mencapai suatu keputusan. ${ }^{18}$

Mengacu kepada pengertian dan ciri-ciri kreativitas berfikir di atas, maka seorang mahasiswa yang sedang dan akan menulis skrispi sangat diperlukan kemampuan dan kreativitas berfikir sebagai upaya menghasilkan skripsi yang berkualitas. Selanjutnya, di era digital saat ini sangat memungkinkan seseorang untuk melakukan plagiarisme. Untuk menghindari sikap plagiarisme, dibutuhkan karya tulis yang original. Originalitas karya tulis seseorang dapat dilihat dari bagaimana dia memberikan gagasan baru dalam penulisan dan menyelesaikan masalah, serta mampu membuat kolaborasi dan kombinasi-kombinasi yang berbeda dari yang sudah ada.

\section{Teknik Penulisan}

Teknik penulisan merupakan suatu tata cara, teknik, prosedur, atau mekanisme dalam menyajikan sebuah karya tulis ilmiah yang sesuai dengan aturan-aturan tertentu. Sebuah karya tulis dianggap ilmiah apabia disajikan berdasarkan logika ilmu pengetahuan yang bersandar pada teori-teori yang dikemukakan oleh para ahli.Selanjutnya, sebuah karya tulis harus pula ditulis secara sistematis.Sebuah karya tulis yang sistematis jika ditulis

\footnotetext{
${ }^{17}$ Herdian:https://herdy07.wordpress.com posted 27 Mei 2010

${ }^{18}$ Ibid, h. 74
} 
berdasarkan kaidah-kaidah penulisan yang telah ditetapkan, disusun atau disepakati oleh para ahli.

Mengingat demikian banyak dan beragamnya kaidah penulisan yang dikemukakan oleh para ahli, maka STAIN Jurai Siwo Metro (sekarang IAIN Metro) dalam hal ini Pusat Penelitian dan Pengabdian Masyarakat (P3M) telah menyusun dan menerbitkan buku Pedoman Penulisan Karya Ilmiah sebagai pedoman dan rambu dalam penulisan karya ilmiah bagi para mahasiswa dan dosen di lingkuangan IAIN Metro. Buku pedoman ini memuat dua kategori, yaitu; 1) Pedoman Umum dan 2) Pedoman Khusus.

(a) Pedoman Umum, yaitu teknik penulisn secara umum yang mencakup; (a) Penggunaan Bahasa; (b) Penulisan Kutipan; (c) Penulisan Catatan Kaki; (d) Penulisan Dafar Pustaka; (e) Penomoran halaman; (f) Jumlah Halaman, dan Penggandaan;

(b) Pedoman Khusus, yaitu pedoman yang secara khusu berkaitan dengan teknik penulis skripsi yang mencakup: (a) Jenis, ukuran dan margin kertas; (b) Jenis dan ukuran huruf; (c) Sistematika Penulisan Skripsi. ${ }^{19}$

Sistematikan penulisan skripsi yaitu pedoman tentang susunan skripsi dalam bentuk laporan hasil penelitian berupa karya tulis ilmiah. Sistematika Penulisan skripsi terdiri dari 3 bagian pokok, yaitu bagian awal, isi dan bagian akhir. Adapun jenis penelitian yang diadpsi dalam buku ini terdiri dari 3 jenis penelitian, yaitu: (1) Penelitian Kualitatif; (2) Penelitian Kuantitatif, dan (3) Penelitian Tindkan Kelas. Dengan adanya buku pedoman ini diharapkan karya tulis ilmiah (skripsi) yang ditulis oleh mahasiswa akan lebih terarah, teratur dan sistematis.

\section{Penguasaan Metodologi Penelitian}

Penelitian atau sering juga disebut research, oleh Yogesh Kumar Singh kata research terdiri dari dua kata yaitu re dan search, "re" mean again and

${ }^{19}$ STAIN Jurai Siwo Metro Buku Pedoman Penulisan Karya Tulis Ilmiah (Edisi Revisi) (Metro: P3M, 2010). 
again, "search" mean to find out something. Therefore, research mean to observe the phenomena again and again from different dimensions. ${ }^{20}$

Pengertian metode penelitian dan metodologi penelitian, menurut C.R. Kothari terdapat perbedaan yang jelas, dimana research method may be understood as all those methods/techniques that are used for conduction of research. Research methodology is a way to systematically solve the research problems and it can be understood as a science of studying how research is done systematically. ${ }^{21}$

Berdasarkan pendapat di atas, dapat dipahami bahwa penelitian adalah sebuah aktivitas untuk mengungkap dan menggali kembali tentang sesuatu dalam dimensi yang berbeda. Dengan demikian, penelitian itu dapat berupa pengungkapan kembali sesatu yang sudah ada atau berupa pengembangan dari sesuatu yang ada saat ini.

Di sisi lain, sering terjadi kekeliran persepsi di kalangan mahasiswa antara metode penelitian dan metodologi penelitian. Sesungguhnya antara keduanya terdapat perbedaan yang sangat mencolok. Di mana metode penelitian adalah merupakan teknik atau langkah-langkah operasional dalam melaksanakan penelitian, sedangkan metodologi penelitian adalah ilmu yang mempelajari atau memecahkan masalah-masalah yang berkaiatan dengan penelitian sehingga penelitian tersebut dapat terlaksana dengan baik-baik, benar dan sistematis.

Secara metodologis, banyak pendapat yang dikemukakan oleh para ahli berdasarkan karakteristik penelitian dan bidang keahlian mereka. Namun inti dari semua teori itu adalah bagaimana membangun sebuah rancangan penelitian berdasarakan filosofis, karakateristik, dan tujuan penelitian yang akan dilaksanakan. Sehingga dalam pelaksanaanya, penelitian tersebut bisa

\footnotetext{
${ }^{20}$ Yogesh Kumar Singh, Fundamental pf Research Methodology and Statistics, (New Delhi: New Age International Publishers, 2006), h.2

${ }^{21}$ C.R Kothary, Research Methodology Methods and Techniques, (New Delhi: New Age International Publishers, 2004) h. 7-8
} 
terarah, logis, ilmiah dan sistematis dan hasilnya pun akan vasil dan dapat dipertanggungjawabkan secara keilmuan.

Berdasarkan karakteristik dan metodenya, secara garis besar John W. Creswell mengelompokkan penelitian menjadi 3 jenis penelitian, yaitu penelitian kualitatif, penelitian kuantitatif dan metode campuran. Di sisi lain John Gerring menyoroti secara khusus tentang peneltian studi kasus atau case study.

Menurut Sugiyono metode penelitian kunatitatif dapat diartikan sebagai metode penelitian yang berlqndaskan pada filsafat positivism, digunakan untuk meneliti pada populasi atau sampel tertentu, pengumpulan data menggunakan instrumen penelitian, analisis data bersifat kunatitatif/ statistic, dengan tujuan untuk menguji hipotesis yang telah ditetapkan, Sedangkan metode penelitian kualitatif adalah metode penelitian yang berlandaskan filsafat postpositivisme, digunakan untuk meneliti pada kondisi objek yang alamiah, (sebagai lawanya adalah eksperimen) di mana peneliti adalah sebagai instrument kunci, teknik pengumpulan data dilakukan secara triangulasi (gabungan), analisis data bersifat induktif/ kualitatif, dan hasil penelitian kualitati lebih menekakan makna dari pada generalisasi. ${ }^{22}$

Terlepas dari metode penelitian yang dipilih oleh peneliti, hal terpenting yang harus dikausai oleh peneliti adalah kemampuan merancang sebuah penelitian. Menurut S Nasution desain penelitian merupakan rencana tentang cara mengumpulkan dan menganalisis data agar dapat dilaksanakan secara ekonomis serta serasi dengan tujuan penelitian. ${ }^{23}$ Sedangkan menurut John W Creswell Rancangan Penelitian merupakan rencana untuk melakukan penelitian. Rancangan ini terdiri dari tiga komponen penting;

${ }^{22}$ Sugiyono, Metode Penelitian Kuantitatif, Kualitatifdan R\&D, (Bandung: Alfabeta, 2015), h. $8-9$

${ }^{23}$ S. Nasution, Metode Research (Penelitian Ilmiah), (Jakarta: Bumi Aksara, 2003), h. 23 
asumsi-asumsi filosofis, strategi-strategi penelitian, dan metode-metode penelitian spesifik. ${ }^{24}$

Dalam hal penguasaan metode penelitian, setidaknya ada 5 hal yang harus dikuasai oleh mahasiswa, yaitu; 1) rancangan penelitian, 2) populasi dan sampel, 3) instrumen penelitian, 4) pengumpulan data, dan 5) analisis data. Kelima hal ini dianggap penting agar karya tulis ilmiah (skripsi) yang di tulis berdasarkan hasil penelitian mahasiswa memenuhi standar keilmuan, logis dan sistematis dengan mengacu kepada teori-teori penelitian ilmiah yang dikemukakan oleh para ahli.

Sebelum proses penulisan skripsi, diawali dengan proses pangajuan calon judul skripsi, mahasiswa terlebih dahulu diwajibkan menempuh dan lulus mata kuliah metodologi penelitian. Dengan demikian, idealnya mahasiswa telah menguasai ilmu tentang metode penelitaian, sehingga dianggap mahasiswa telah memiliki kemampuan dalam melaksanakan penelitian. Namun pada kenyataannya, masih banyak mahasiswa yang mengalami kesulitan pada saat menulis skripsi. Hal ini dapat dilihat ketika melaksanakan seminar proposal atau pun pada saat ujian skripsi (munaqosyah).

\section{Hasil Kreativitas Berfikir, Teknik Penulisan dan Penguasaan Metodologi Penelitian: Melihat Hasil Skripsi Mahasiswa STAIN Metro}

Berdasarkan hasil pengamatan tentang skripsi yang ditulis mahasiswa di perpustakaan periode 2010-2015, diketahui beberapa hal sebagai berikut:

\section{Skripsi Mahasiswa Berdasarkan Tahun Penulisan}

Berdasarkan tahun penulisannya, diketahui jumlah skripsi mahasiswa pada periode 2010-2015 adalah sebanyak 4.837 eksamplar, dengan rincian sebagai berikut:

${ }^{24}$ John W. Creswell, Research Design Pendekatan Kualitatif, kuantitatif dan Mixed, Penerjemah Achmad Fawaid, (Yogyakarta: Pustaka Pelajar, 2013), h. xii 
Tabel 1. Skripsi Mahasiswa Berdasarkan Tahun Penulisan

\begin{tabular}{|c|l|l|}
\hline No & \multicolumn{1}{|c|}{ Tahun Terbit } & \multicolumn{1}{c|}{ Jumlah } \\
\hline 1 & 2010 & 784 \\
\hline 2 & 2011 & 812 \\
\hline 3 & 2012 & 817 \\
\hline 4 & 2013 & 792 \\
\hline 5 & 2014 & 813 \\
\hline 6 & 2015 & 819 \\
\hline \multicolumn{2}{|c|}{ Total } & 4.837 \\
\hline
\end{tabular}

Sumber: Perpustakaan STAIN Metro Tahun 2015

\section{Skripsi Mahasiswa Berdasarkan Tempat Penelitian}

Berdasarkan tempatnya penelitian yang dilakukan oleh mahasiswa STAIN Jurai Siwo Metro sampai dengan periode 2010-2015, dilaksanakan di dua tempat, yaitu di lapangan dan perpustakaan, dengan rincian sebagai berikut:

Tabel 2 : Skripsi Mahasiswa Berdasarkan Tempat Penelitian

\begin{tabular}{|c|l|c|c|}
\hline No & \multicolumn{1}{|c|}{ Tempat } & Jumlah & Prosentase \\
\hline 1 & Lapangan & 3.187 & $65,88 \%$ \\
\hline 2 & Perpustakaan & 1.650 & $34,12 \%$ \\
\hline & Total & 4.837 & $100 \%$ \\
\hline
\end{tabular}

Sumber: Perpustakaan STAIN Metro Tahun 2015

\section{Skripsi Mahasiswa Berdasarkan Jenis Penelitian}

Berdasarkan Jenis Penelitian yang dipilih mahasiswa dalam melakukan penelitian, diketahui ada 3 jenis penelitian, yaitu; 1) penelitian kualitatif, 2) penelitian kuantitatif, dan 3) Penelitian Tindakan Kelas (PTK). Ketiga jenis penelitian tersebut dapat dijelaskan sebagai berikut: 
Tabel 3 : Penenlitian Mahasiswa Berdasarkan Jenisnya

\begin{tabular}{|c|l|l|l|}
\hline No & \multicolumn{1}{|c|}{ Jenis Penelitian } & \multicolumn{1}{c|}{ Jumlah } & \multicolumn{1}{c|}{ Prosesntase } \\
\hline 1 & Kuantitatif & 2.102 & $43,46 \%$ \\
\hline 2 & Kualitatif & 1.217 & $25,16 \%$ \\
\hline 3 & PTK & 1.518 & $31,38 \%$ \\
\hline \multicolumn{2}{|c|}{ Total } & 4.837 & $100 \%$ \\
\hline
\end{tabular}

Sumber: Perpustakaan STAIN Metro Tahun 2015

\section{Skripsi Mahasiswa Berdasarkan Sifat dan Bentuk Penelitian}

Berdasarkan sifat dan bentuknya, skripsi yang ditulis mahasiswa STAIN Jurai Siwo Metro periode 2010-2015, dapat dikategorikan menjadi 5 kategori, yaitu; 1) Deskriptif Kuantitaif, 2) Deskriptif Kualitatif, 3) Kajian Tematik, 4) Kajian Tokoh dan Kajian Historis. Kelima kategori tersebut dapat dijelaskan sebagai berikut:

Tabel 4: Sksipsi Mahasiswa Berdasarkan Sifat dan Bentuknya

\begin{tabular}{|c|l|c|c|}
\hline No & \multicolumn{1}{|c|}{ Sifat dan Bentuk } & Jumlah & Prosentase \\
\hline 1 & Deskriptif Kuantitatif & 3.160 & $65,33 \%$ \\
\hline 2 & Deskriptif Kualitatif & 1.423 & $29,42 \%$ \\
\hline 3 & Kajian Tematik & 127 & $2,63 \%$ \\
\hline 4 & Kajian Tokoh & 71 & $1,47 \%$ \\
\hline 5 & Kajian Historis & 56 & $1,15 \%$ \\
\hline \multicolumn{2}{|l|}{ Total } & 4.837 & $100 \%$ \\
\hline
\end{tabular}

Sumber: Perpustakaan STAIN Metro Tahun 2015

\section{Skripsi Mahasiswa Berdasarkan Tingkat Kreativitas Berfikir}

Tingkat kreativitas berfikir mahasiswa STAIN Jurai Siwo Metro dalam menulis skripsi, dapat diklasifikasikan ke dalam 3 kelompok, yaitu ; 1) tinggi, 2) sedang, dan 3) rendah. Berdasarkan hasil pengamatan skripsi 
mahasiswa STAIN Jurai Siwo Metro pada periode 2010-2015, ketiga kelompok tersebut dapat dijelaskan sebagai berikut:

Tabel 5: Skripsi Mahasiswa Berdasarkan Tingkat Kreativitas Berfikir

\begin{tabular}{|c|l|c|c|}
\hline No & \multicolumn{1}{|c|}{ Tingkat Kreativitas Berfikir } & Jumlah & Prosentase \\
\hline 1 & Tinggi & 222 & $4,59 \%$ \\
\hline 2 & Sedang & 1.247 & $25,78 \%$ \\
\hline 3 & Rendah & 3.368 & $69,63 \%$ \\
\hline \multicolumn{2}{|c|}{ Total } & 4.837 & $100 \%$ \\
\hline
\end{tabular}

Sumber: Perpustakaan STAIN Metro Tahun 2015

Berdasarkan hasil temuan di atas dapat dipahami bahwa secara umum kreativitas berfikir mahasiswa dalam menulis skripsi masih rendah. Hal ini dapat dilihat dari masih banyaknya skripsi mahasiswa memiliki kesamaan judul, tema, jenis, isi dan bahkan dalam hal tulisan dan kata-kata. Rendahnya kreativitas berfikir mahasiswa ini disebabkan karena beberapa hal, antara lain;

(a) Mahasiswa mengalami kesulitan dalam menemukan permasalahan penelitian

(b) Mahasiswa mengalami kesuliatan dalam menemukan ide baru

(c) Mahasiswa mengalami kesulitan dalam merangkai kata atau kalimat

(d) Masih lemahnya kemampuan mahasiswa dalam penguasaan bahasa asing (Arab \& Inggris) bagi mereka yang menulis skripsi dalam dua bahasa ini

(e) Terbatasnya literatur yang dimiliki mahasiswa dan yang tersedia di perpustakaan STAIN Jurai Siwo Metro saat ini.

Sementara itu, untuk menyikapi permasalah ini, tentunya berbagai pihak dapat mengambil peran strategis, di antaranya;

a) Mahasiswa agar lebih aktif dan banyak membaca karya tulis atau hasil penelitian orang lain 
b) Dosen pembimbing skripsi agar lebih intensif dalam mengarahkan dan membimbing kegiatan penulisan skripsi mahasiswa.

c) Pihak STAIN Jurai Siwo Metro agar memprioritaskan pengadaan literature baik yang berbahasa Indonesia maupun berbahasa asing (Arab \& Inggris)

\section{Skripsi Mahasiswa Berdasarkan Penerapan Teknik Penulisan}

Buku Pedoman Penulisan Karya Ilmiah yang diterbitkan oleh Pusat Penelitian dan Pengabdian pada Masyarakat (P3M) STAINJurai Siwo Metro pada Tahun 2010 adalah satu-satunya acuan bagi mahasiswa STAIN Jurai Siwo Metro dalam penerapan teknik penulisan skripsi., Berdasarkan hasil pengamatan, penerapan teknik penulisan yang dilakukan mahasiswa dapat dikategorikan ke dalam 3 kategori, yaitu; 1) sesuai, 2) kurang sesuai, dan 3) tidak sesuai. Ketiga kategori tersebut dapat dijelaskan pada table berikut:

Tabel 6 : Skripsi Mahasiswa Berdasarkan Penerapan Teknik Penulisan

\begin{tabular}{|c|l|l|l|}
\hline No & Penerpan Teknik Penulisan & \multicolumn{1}{|c|}{ Jumlah } & Prosentase \\
\hline 1 & Sesuai & 1.712 & $35,39 \%$ \\
\hline 2 & Kurang Sesuai & 1.518 & $31,38 \%$ \\
\hline 3 & Tidak Sesuai & 1.607 & $33,23 \%$ \\
\hline \multicolumn{2}{|c|}{ TOTAL } & 4.837 & $100 \%$ \\
\hline
\end{tabular}

Sumber: Perpustakaan STAIN Metro Tahun 2015

Teknik penulisan skripsi sebagaimana telah dimuat dalam buku pedoman penulisan karya ilmiah STAIN Jurai Siwo Metro. Namun berdasarkan hasil temuan penelitian, masih hanya $35,39 \%$ dari mahasiswa yang telah menerapkan teknik penulisan karya ilmiah yang sesuai dengan buku pedoman. Sementara 31,38\% kurang sesuai dan 33,23\% tidak sesuai dengan buku pedoman.

Ketidaksesuain teknik penulisan ini dapat dilihat di beberapa aspek, meliputi: 
(a) Penulisan catatan kaki (footnote)

(b) Penulisan Daftar Pustakan (Bibliography)

(c) Penulisan kutipan

(d) Penomoran Judul dan sub Judul

(e) Penomoran Halaman

Masih banyaknya ketidaksesuain teknik penulisan ini disebabkan oleh beberapa hal, antara lain:

(a) Masih banyaka mahasiswa yang malas memperhatikan buku pedoman penulisan karya ilmiah yang tersedia

(b) Pembimbing skripsi cenderung kurang memperhatikan teknik penulisan dan lebih focus kepada isi dan metodologi penelitian

(c) Mahasiswa cenderung mencontoh teknik penulisan skripsi yang sudah ada di perpustakaan yang terkadang juga masih banyak mengandung kesalahan dalam teknik penulisan.

Untuk mengatasi kesalahan dalam teknik penulisan ini perlu kiranya mahasiswa memperhatikan buku pedoman penulisan karya ilmiah yang diterbitkan oleh STAIN Jurai Siwo Metro dan agar dosen pembimbing skripsi lebih perhatian pada teknik penulisan.

\section{Skripsi Mahasiswa Berdasarkan Penguasaan Metodologi Penelitian}

Penguasaan metodologi penelitian adalah hal mutlak yang harus dimiliki mahasiswa dalam melakukan penelitian, Berdasarkan hasil pengamatan terhadap skripsi mahasiswa STAIN Jurai Siwo Metro dalam kurun waktu 2010-2015, penguasaan metodologi penelitian mahasiswa dapat dikelompokkan menjadi 3, yaitu; 1) mengusai, 2) kurang menguasai, dan 3) tidak menguasai. Ketiga klasifikasi tersebut dapat dijabarkan pada table berikut: 


\begin{tabular}{|c|l|c|c|}
\hline No & Penguasaan Metodologi Penelitian & Jumlah & Prosentase \\
\hline 1 & Menguasai & 1.714 & $35,43 \%$ \\
\hline 2 & Kurang Menguasai & 1.721 & $35,58 \%$ \\
\hline 3 & Tidak Menguasai & 1.402 & $28.99 \%$ \\
\hline \multicolumn{2}{|c|}{ Total } & 4.837 & $100 \%$ \\
\hline
\end{tabular}

Sumber: Perpustakaan STAIN Metro Tahun 2015

Penguasaan metodologi penelitian adalah merupakan hal yang terpenting dalam penulisan sebuah karya ilmiah terutama skripsi yang merupakan laporan hasil penelitian. Jika dilihat dari segi penguasaan metodologi penelitian, ditemukan bahwa sebanyak $35,43 \%$ mahasiswa telah menguasai metodologi penelitian, sedang $35,48 \%$ kurang menguasai dan $28,99 \%$ tidak menguasai.

Meskipun mahasiswa relatif telah menguasai metodologi penelitian, namun masih banyak ditemukan kelemahan dalam hal; (a) Mengidentifikasi masalah; (b) Merancang desain penelitian; (c) Merumuskan definisi operasional variabel; (d) Menentukan populas, sampel dan teknik pengambilan sampel; (e) Mengembangkan instrument pengumpul data; (f) Melakukan analisis data; (g) Pembahasan hasil penelitian.

Adapun kelemahan-kelemahan yang dialami oleh mahasiswa dalam penguasaan metodologi penelitian ini disebabkan beberapa hal, yaitu: (1) Mahasiswa kurang kreatif dalam menemukan masalah penelitian; (2) Terlalu luas dan banyaknya jenis penelitian yang harus dikuasai oleh mahasiswa; (3) Terlalu luasnya pokok bahasan mata kuliah metodologi penelitian, sedangkan alokasi waktu yang tersedia sangat terbatas; (4) Mahasiswa kurang menguasai ilmu pendukung metodologi penelitian, seperti ilmu statistic, pengembangan instrumen pengumpul data, dan penguasaan teori yang relevan; (5) Kecenderungan dosen pembimbing skripsi lebih menguasai salah satu jenis penelitian.

Memperhatikan hasil temuan di atas, untuk menyelesaikan masalah penguasaan metodologi penelitian ini, dirasa perlu adanya: 
(a) Penambahan alokasi waktu untuk mata kuliah metodologi penelitian

(b) Dosen pengampu mata kuliah metodologi penelitian agar lebih menekankan pada sisi praktis daripada penguasaan teoritis

(c) Mata kuliah pendukung penulisan skripsi agar lebih diintensifkan

(d) Ketua Program Studi agar mengarahkan jenis penelitian mahasiswa sesuai dengan keahlian dosen pembimbing skripsinya.

\section{Kesimpulan}

Berdasarkan temuan penilitian dan hasil pembahasan di atas, terkait dengan kualitas skripsi yang ditulis mahasiswa STAIN Jurai Siwo Metro pada periode 2010-2015, dapat disimpulkan bahwa kreativitas berfikir mahasiswa masih relatif rendah bila dilihat dari sisi orisinalitas tulisan dalam skripsi mahasiswa STAIN Jurai Siwo Metro periode 2010-2015. Selain itu, pemahaman dan penerapan teknik penulisan, sebagain besar telah sesuai dengan buku pedoman penulisan karya ilmiah yang diterbitkan oleh STAIN Jurai Siwo Metro.

Selanjutnya, penguasaan metodologi penelitian mahasiswa relative telah menguasai, namun masih ditemukan beberapa kelemahan dalam penerapannya dalam penulisan skripsi. Kemudian, peran dosen pembimbing skrispi masih perlu dioptimalkan, dan peran dosen pengampu mata kuliah metodologi penelitian serta mata kuliah lainya belum maksimal.[]

\section{Daftar Pustaka}

C.R Kothary, Research Methodology Methods and Techniques, New Delhi: New Age International Publishers, 2004

Data Subbag Akademik, Kemahasiswaan dan Alumni STAIN Jurai Siwo Metro, Tahun 2015

Fisher, Haris, R. Introduction to Creative Thinking. http://www.virtualsalt. com/ itdt.htm 
Fisher, R. Teaching Children to Think, London: Stanley Thornes Ltd, 1995

Herdian: https://herdy07.wordpress.com posted 27 Mei 2010

Herdian:https://herdy07.wordpress.com posted 27 Mei 2010

http://iesp.feb.unpad.ac.id

https://machdarhelmi.wordpress.com.

https://v17a3.wordpress.com

John W. Creswell, Research Design Pendekatan Kualitatif, kuantitatif dan Mixed, Penerjemah Achmad Fawaid, Yogyakarta: Pustaka Pelajar, 2013

LTSIN, Learning teaching, Scotland: Learning and Teaching Scotland, 2004

S. Nasution, Metode Research (Penelitian Ilmiah), Jakarta: Bumi Aksara, 2003

STAIN Jurai Siwo Metro Buku Pedoman Penulisan Karya Tulis Ilmiah, Edisi Revisi) (Metro: P3M, 2010.

Sugiyono, Metode Penelitian Kuantitatif, Kualitatif dan R\&D, Bandung: Alfabeta, 2015

Utami Munandar, Pengembangan Kreativitas Anak Berbakat, Jakarta: Renika Cipta, 2009

Yatim Riyanto, Paradigma Baru Pembelajaran sebagai Referensi bagi Pendidik dalam Implementasi Pembelajaran yang Efektif dan Berkualitas, Jakarta: Kencana, 2014

Yogesh Kumar Singh, Fundamental pf Research Methodology and Statistics, New Delhi: New Age International Publishers, 2006 